\section{SOI: $1.1 /$ TAS DOI: $10.15863 /$ TAS International Scientific Journal Theoretical \& Applied Science}

p-ISSN: 2308-4944 (print) e-ISSN: 2409-0085 (online)

Year: 2018 Issue: 09 Volume: 65

Published: $25.09 .2018 \quad \underline{\text { http://T-Science.org }}$

SECTION 7. Mechanics and machine construction.
Denis Chemezov M.Sc.Eng., Corresponding Member of International Academy of Theoretical and Applied Sciences, Lecturer of Vladimir Industrial College, Russian Federation chemezov-da@yandex.ru

Svetlana Tyurina Lecturer of Vladimir Industrial College, Russian Federation swetl.tyurina2015@yandex.ru

Irina Pavluhina Lecturer of Vladimir Industrial College, Russian Federation

Oleg Gorbatenko Master of Industrial Training, Vladimir Industrial College, Russian Federation

Irina Medvedeva Master of Industrial Training, Vladimir Industrial College, Russian Federation

\title{
CALCULATION OF VON MISES STRESS AT PLASTIC DEFORMATION OF A STEEL BUSHING
}

Abstract: Stress condition of a steel bushing after short-term plastic deformation is presented in the article. The analytical formula for determining of von Mises stress at plastic deformation of the steel bushing is obtained.

Key words: stress, a bushing, tensor, a model, plastic deformation.

Language: English

Citation: Chemezov D, Tyurina S, Pavluhina I, Gorbatenko O, Medvedeva I (2018) CALCULATION OF VON MISES STRESS AT PLASTIC DEFORMATION OF A STEEL BUSHING. ISJ Theoretical \& Applied Science, 09 (65): 201-203.

Soi: http://s-o-i.org/1.1/TAS-09-65-35 Doi: crossef https://dx.doi.org/10.15863/TAS.2018.09.65.35

\section{Introduction}

Hollow metal parts (for example, bushings and liners) are exposed to plastic deformation under external loads during operation [1]. Stresses of various kinds occur in material of the part. A calculation of a value and a distribution in a volume of stresses is carried out taking into account the physical and mechanical properties of material, sizes of the part, action time of loads and other conditions of plastic deformation. A number of multidirectional stresses in material of the deformed part can be presented by von Mises stress (equivalent stress) [2]. The calculated value of von Mises stress must be less than maximum allowable stress in material of the part in comparing. Safety margin of material at shortterm plastic deformation of the thin-walled part has determined from the ratio of two stresses. Let us consider stress-strain condition of the thin-walled part in condition of constant radial external force application.

\section{Materials and methods}

The calculation of von Mises stress was performed in the COMSOL Multiphysics (Structural Mechanics Module) software environment [3].

The three-dimensional solid-state bushing model was exposed to plastic deformation. Quality structural steel 1045 (UNS G10450) was accepted as material of the bushing model [4]. The outer diameter of the bushing model was accepted by the value of $40 \mathrm{~mm}$, the inner diameter of the bushing model was accepted by the value of $30 \mathrm{~mm}$. Constant distributed force of $1 \mathrm{kN}$ by duration of $1 \mathrm{~s}$ acted on the outer cylindrical surface of the steel bushing model. Load was absent in axial direction. The steel bushing model was fixed (the inner cylindrical surface).

The following conditions were accepted for the calculation of stress condition of the steel bushing model at plastic deformation $(1-11)$ :

1. Solid mechanics

$$
\rho \frac{\partial^{2} u}{\partial t^{2}}=\nabla \cdot F S+F v
$$




\begin{tabular}{|c|c|c|c|c|c|c|}
\hline \multirow{4}{*}{ Impact Factor: } & ISRA (India) & $=1.344$ & SIS (USA) & $=0.912$ & ICV (Poland & $=6.630$ \\
\hline & ISI (Dubai, UAE & $=0.829$ & РИНЦ (Russia) & $=0.156$ & PIF (India) & $=1.940$ \\
\hline & GIF (Australia) & $=0.564$ & ESJI (KZ) & $=4.102$ & IBI (India) & $=4.260$ \\
\hline & JIF & $=1.500$ & SJIF (Morocco) & $=5.667$ & & \\
\hline
\end{tabular}

$$
F=I+\nabla u
$$

where $\rho$ is density; $u$ is displacement field; $t$ is time; $\nabla$ is gradient; $F$ is force; $S$ is the second PiolaKirchhoff stress tensor [5]; $F v$ is load defined as force per the unit volume; $I$ is unit tensor.

2. Linear elastic material

$$
\begin{gathered}
\rho \frac{\partial^{2} u}{\partial t^{2}}=\nabla \cdot S+F v \\
S=S_{a d}+C: \varepsilon_{e l} \\
\varepsilon_{e l}=\varepsilon-\varepsilon_{\text {inel }} \\
S_{a d}=S_{0}+S_{e x t}+S_{q} \\
\varepsilon_{\text {inel }}=\varepsilon_{o}+\varepsilon_{t h}+\varepsilon_{h s}+\varepsilon_{p l}+\varepsilon_{c r} \\
\varepsilon=\frac{1}{2}\left[(\nabla u)^{T}+\nabla u\right]
\end{gathered}
$$

where $S_{a d}$ is additive stress [6]; $C$ is the fourth-order elasticity tensor [7]; $\varepsilon_{e l}$ is elastic strain; $\varepsilon$ is total strain tensor; $\varepsilon_{\text {inel }}$ is inelastic strain; $S_{0}$ is initial stress; $S_{\text {ext }}$ is external stress; $S_{q}$ is stress (viscous damping); $\varepsilon_{0}$ is initial strain; $\varepsilon_{t h}$ is thermal strain; $\varepsilon_{h s}$ is hygroscopic strain; $\varepsilon_{p l}$ is plastic strain; $\varepsilon_{c r}$ is creep strain; $T$ is temperature.

3. Boundary load

$$
S \cdot n=F_{A}
$$

$$
F_{A}=\frac{F_{t o t}}{A}
$$

where $n$ is outward unit normal vector; $F_{A}$ is load defined as force per the unit area; $F_{\text {tot }}$ is total force; $A$ is the cross section area.

\section{Fixed constraint}

$$
u=0
$$

Mesh statistics: minimum element quality 0.2487 , average element quality -0.7027 , tetrahedral elements - 3227, triangular elements - 1304, edge elements -132 , vertex elements -8 .

\section{Results and discussion}

Calculated von Mises stress in the steel bushing model after plastic deformation is presented in the Fig. 1.

Maximum equivalent stress of material was distributed in surface layers of a hole after removing of external load from the outer surface of the bushing model. Maximum von Mises stress, when considering of the end surface of the bushing model, was found in the second and the fourth quarters of the $X Y$ coordinate plane. The volume of the bushing model, which was located in the first quarter of the $X Y$ coordinate plane, was less exposed to equivalent stress. Von Mises stress reached the value up to 950 $\mathrm{kN} / \mathrm{m}^{2}$.

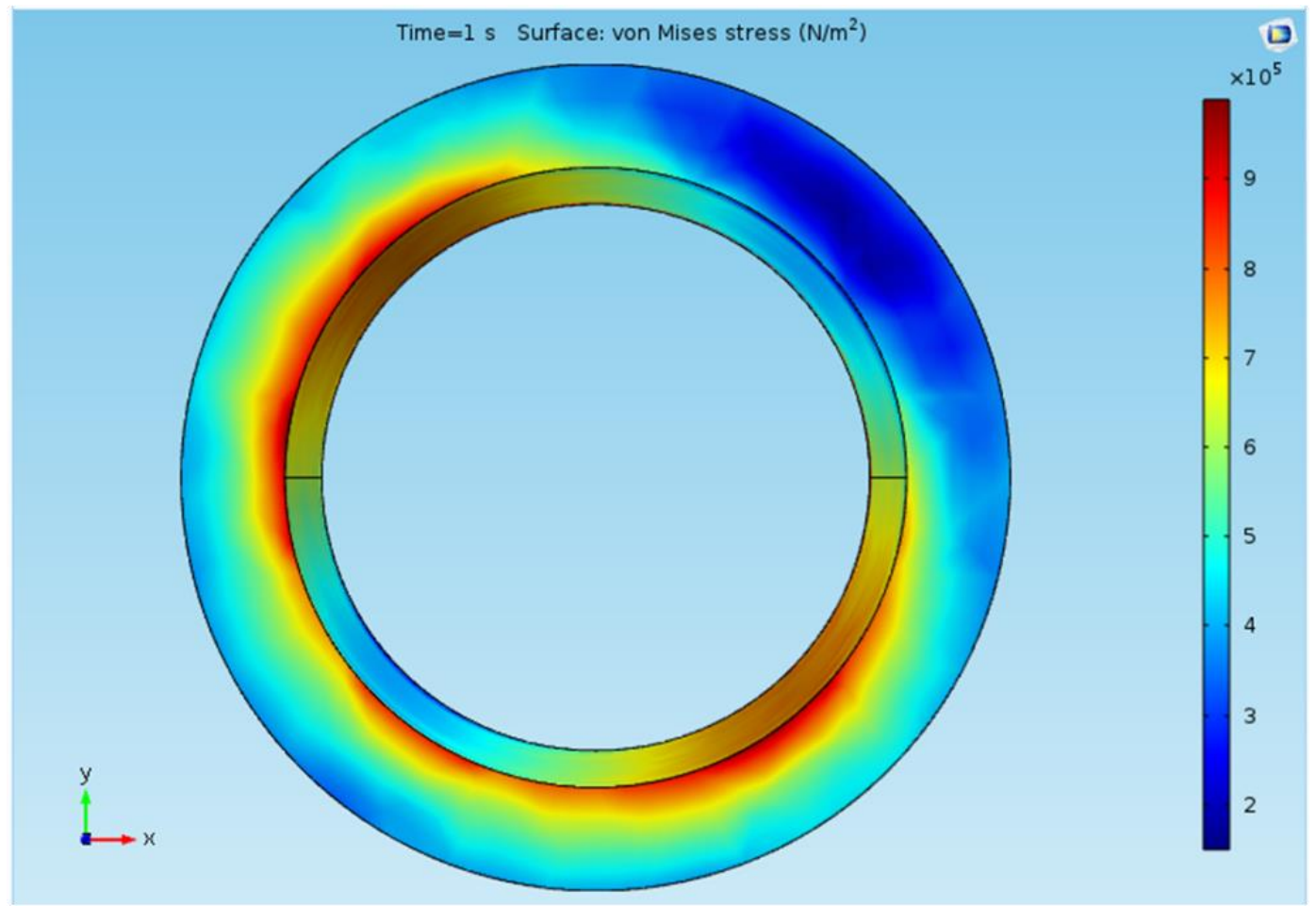

Figure 1 - Von Mises stress in the steel bushing model after plastic deformation.

Maximum allowable stress (tensile strength) of quality steel 1045 is $600000 \mathrm{kN} / \mathrm{m}^{2}$. This means that material of the bushing model can withstand external loads by the value in 600 times more than external load applied in accordance with conditions of the problem.

Von Mises stress can be presented in the mathematical form (12) 


\begin{tabular}{|c|c|c|c|c|c|c|}
\hline Impact Factor: & $\begin{array}{l}\text { ISRA (India) } \\
\text { ISI (Dubai, UAE } \\
\text { GIF (Australia) } \\
\text { JIF }\end{array}$ & $\begin{array}{l}=1.344 \\
=0.829 \\
=0.564 \\
=1.500\end{array}$ & $\begin{array}{l}\text { SIS (USA) } \\
\text { PИНЦ (Russia) } \\
\text { ESJI (KZ) } \\
\text { SJIF (Morocco) }\end{array}$ & $\begin{array}{l}=0.912 \\
=0.156 \\
=4.102 \\
=\mathbf{5 . 6 6 7}\end{array}$ & $\begin{array}{l}\text { ICV (Poland) } \\
\text { PIF (India) } \\
\text { IBI (India) }\end{array}$ & $\begin{array}{l}=6.630 \\
=1.940 \\
=4.260\end{array}$ \\
\hline
\end{tabular}

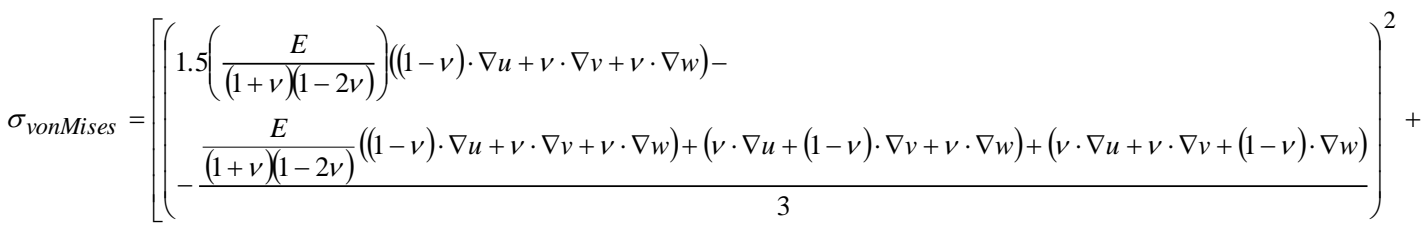

$$
\begin{aligned}
& +2\left[\frac{E}{1+v}(\nabla v+\nabla u)\right]+2\left[\frac{E}{1+v}(\nabla w+\nabla u)\right]^{2}+ \\
& +\left(\begin{array}{l}
\frac{E}{(1+v)(1-2 v)}(v \cdot \nabla u+(1-v) \cdot \nabla v+v \cdot \nabla w)- \\
\frac{E}{(1+v)(1-2 v)}((1-v) \cdot \nabla u+v \cdot \nabla v+v \cdot \nabla w)+(v \cdot \nabla u+(1-v) \cdot \nabla v+v \cdot \nabla w)+(v \cdot \nabla u+v \cdot \nabla v+(1-v) \cdot \nabla w) \\
-\frac{1}{3}
\end{array}\right)^{2}+ \\
& +2\left[\frac{E}{1+v}(\nabla w+\nabla v)\right]^{2}+ \\
& +\left(\begin{array}{l}
\frac{E}{(1+v)(1-2 v)}(v \cdot \nabla u+v \cdot \nabla v+(1-v) \cdot \nabla w)- \\
\frac{E}{(1+v)(1-2 v)}((1-v) \cdot \nabla u+v \cdot \nabla v+v \cdot \nabla w)+(v \cdot \nabla u+(1-v) \cdot \nabla v+v \cdot \nabla w)+(v \cdot \nabla u+v \cdot \nabla v+(1-v) \cdot \nabla w) \\
-\frac{(1+2)}{2}
\end{array}\right)^{0.5}
\end{aligned}
$$

where $E$ is the Young's modulus; $v$ is the Poisson's ratio; $\nabla u, \nabla v, \nabla w$ are displacement gradients.

\section{Conclusion}

Evenly distributed radial force leads to asymmetric stresses in material of the bushing model. Stresses symmetry in material of the bushing model is observed in the $X Z$ and $Y Z$ coordinate planes, since the coefficients $\left[\frac{E}{1+v}(\nabla w+\nabla u)\right]^{2}$ and $\left[\frac{E}{1+v}(\nabla w+\nabla v)\right]^{2}$ in the formula (12) are equal.

\section{References:}

1. Honeycombe RWK (1968) The plastic deformation of metals. London, Edward Arnold. 477 p.

2. Newman K (2010) CT mechanical limits. Scientific and practical journal «Coiled tubing times», №1, 31. pp. 36 - 43.

3. COMSOL Multiphysics User's Guide. COMSOL 4.0a, 2010. $804 \mathrm{p}$.

4. (2018) Properties of 1045 Steel. Available: https://sciencing.com/list-7372308-properties1045-steel.html (Accessed: 25.09.2018).
5. (2018) Stress: first and second Piola-Kirchhoff stress tensors. Available: https://sameradeebnew.srv.ualberta.ca/stress/first-and-secondpiola-kirchhoff-stress-tensors/ (Accessed: 25.09.2018).

6. Li HL et al (2014) Effect of Hydrogen Induced Additional Stress on the Influence on HighStrength Steels. Advanced Materials Research, Vols. 887 - 888. pp. $214-218$.

7. Auricchio F (2014) Quick review on elasticity. Elementi di Meccanica Computazionale Corso di Laurea in Ingegneria Civile Pavia. 117 p. 